
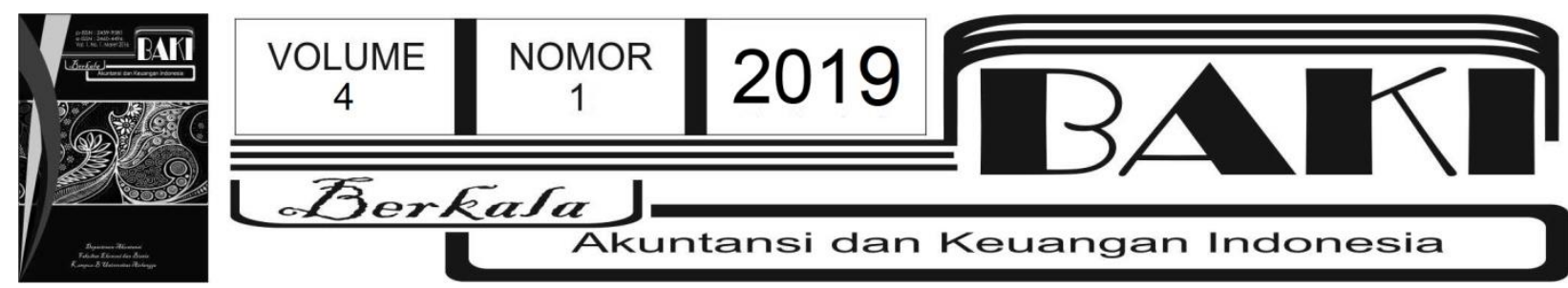

\title{
Manajemen Laba di Sekitar Peristiwa Penawaran Saham Tambahan
}

\author{
Andreas Vernando ${ }^{1,2}$ \\ Sumaryanto ${ }^{1,3}$ \\ ${ }^{1}$ Universitas Ahmad Dahlan \\ 2andreas.vernando@act.uad.ac.id \\ 3sumaryanto@act.uad.ac.id
}

INFO ARTIKEL

Histori Artikel:

Tanggal Masuk 31 Januari 2019

Tanggal Diterima 30 Maret 2019

Tersedia Online 14 Juni 2019

\section{Kata Kunci:}

SEO; Manajemen Laba Akrual; Manajemen Laba Real

\section{A B STRAK}

Penawaran saham tambahan merupakan determinan perusahaan melakukan manajemen laba (Teoh et al., 1998b; Rangan 1998; Shivakumar 2000; Kim dan Park 2005; Cohen dan Zarowin 2010). Akan tetapi, hasil penelitian sebelumnya tidak selaras dengan hasil penelitian Ball and Shivakumar (2008). Ball and Shivakumar (2008) berargumen bahwa perusahaan tidak melakukan manajemen laba sebelum melakukan penawaran saham perdana karena terdapat regulasi yang baik di US dan UK. Mekanisme pengawasan yang kuat seperti di US dan UK mungkin tidak berlaku di Indonesia. Cheung et al., (2014) menggunakan instrumen survey untuk menilai kualitas praktik tata kelola perusahaan di Asian Emerging Markets. Hasil penelitian Cheung et al., (2014) menyajikan bukti bahwa Indonesia merupakan negara yang memiliki Indeks Tata Kelola Perusahaan paling buruk di antara China, Hongkong, Thailand dan Pilipina. Perbedaan penelitian ini dengan penelitian sebelumnya ialah selain menggunakan analisis uji beda, penelitian ini menggunakan analisis regresi guna mendapatkan hasil yang lebih komprehensif. Penelitian ini menggunakan alat analisis wilcoxon signed rank test untuk membandingkan manajemen laba akrual dan real sebelum dan setelah penawaran saham tambahan. Selain itu, penelitian ini menggunakan analisis regresi berganda untuk mendeteksi apakah peristiwa saham tambahan berpengaruh terhadap manajemen laba dengan menyertakan variabel determinan yang lain. Hasil uji beda menunjukkan bahwa perusahaan menggunakan manajemen laba akrual dan real pada saat peristiwa saham tambahan. Lebih lanjut, hasil analisis regresi berganda menyediakan bukti yang serupa yakni perusahaan menggunakan manajemen laba akrual dan real pada saat peristiwa saham tambahan, setelah mengontrol variabel determinan yang lain. 


\section{Pendahuluan}

Penelitian mengenai manajemen laba yang dilakukan di sekitar penawaran saham baik perdana ataupun tambahan sudah cukup komprehensif. Hal ini didasari oleh banyaknya penelitian yang mengkonfirmasi bahwa perusahaan berusaha meningkatkan laba dengan melakukan manajemen laba sebelum melakukan penawaran saham perdana (Teoh et al., 1998a; Gumanti 2001: Jaggi et al., 2006).

Selain penawaran saham perdana, penawaran saham tambahan (SEO) merupakan determinan perusahaan melakukan manajemen laba (Teoh et al., 1998b; Rangan 1998; Shivakumar 2000; Kim dan Park 2005; Cohen dan Zarowin 2010). Akan tetapi, hasil penelitian sebelumnya tidak selaras dengan hasil penelitian Ball and Shivakumar (2008) yang mendokumentasikan bahwa perusahaan tidak melakukan manajemen laba sebelum melakukan penawaran saham.

Ball and Shivakumar (2008), dengan menggunakan data di US dan UK, melaporkan bahwa perusahaan tidak melakukan manajemen laba sebelum melakukan penawaran saham perdana. Hal ini karena terdapat regulasi yang baik serta mekanisme pengawasan (monitoring) internal dan eksternal yang kuat seperti dewan komisaris, auditor internal dan eksternal, agen peratingan, dan analis.

Mekanisme pengawasan yang kuat seperti di US dan UK mungkin tidak berlaku di Indonesia. Cheung et al., (2014) menggunakan instrumen survey untuk menilai kualitas praktik tata kelola perusahaan di Asian Emerging Markets. Hasil penelitian Cheung et al., (2014) menyajikan bukti bahwa Indonesia merupakan negara yang memiliki Indeks Tata Kelola Perusahaan paling buruk di antara China, Hongkong, Thailand dan Pilipina. Karena Indonesia masih dalam kategori paling buruk mengenai regulasi mengenai Tata Kelola Perusahaan, terdapat probabilitas bahwa perusahaan-perusahaan di Indonesia masih mengunakan manajemen laba guna meningkatkan laba sebelum melakukan penawaran saham tambahan. Penelitian ini bertujuan untuk menguji apakah perusahaan berusaha untuk meningkatkan laba dengan menggunakan manajemen laba sebelum melakukan penawaran saham tambahan.

Penelitian ini menggunakan analisis uji beda dan regresi berganda guna mendapatkan hasil yang lebih komprehensif dengan mengikutsertakan variabel determinan yang lain dalam menguji pengaruh peristiwa penawaran saham tambahan terhadap manajemen laba. Bhuiyan (2015) berargumen bahwa penelitian sebelumnya yang menginvestigasi manajemen laba di sekitar penawaran saham tambahan hanya menggunakan analisis univariat dimungkinkan mendapatkan hasil yang bias karena tidak menyertakan variabel determinan yang lain.

Penelitian ini menggunakan analisis regresi untuk mendapatkan hasil yang lebih komprehensif dengan memasukkan beberapa variabel independen lain yang mungkin berpengaruh terhadap hubungan penawaran saham tambahan dengan manajemen laba. 
Penggunaan analisis regresi berganda untuk menguji perbedaan sudah pernah dilakukan oleh Ali dan Zhang (2015) yang berhipotesis yakni overstatement laba lebih besar di tahun-tahun awal dari masa kerjanya daripada di tahun-tahun mendatang dari masa kerjanya. Selain itu, Alali dan Yeh (2012) membandingkan karakteristik risiko cloud computing company dan noncloud computing company dengan menggunakan analisis regresi logistik.

\section{Tinjauan Pustaka}

\subsection{Teori Respon Manajerial}

Shivakumar (2000) mengembangkan model manajemen laba sebelum penawaran saham sebagai hasil dari ekspektasi rasional. Teori respon manajerial berargumen bahwa perusahaan akan melakukan manajemen laba sebelum melakukan penawaran saham sebagai respon rasional manajer dalam rangka mengantisipasi perilaku partisipan pasar pada saat pengumuman penawaran saham (Shivakumar 2000). Formalisasi dari argumen ini dituangkan dalam tabel 2.1.

\section{Tabel 2.1. Pay Off dari Permainan Manajemen Laba Antara Perusahaan dan Partisipan Pasar}

\begin{tabular}{|c|c|c|}
\hline \multirow[b]{2}{*}{ Pada saat penawaran saham } & \multicolumn{2}{|c|}{ Sebelum pengumuman penawaran saham } \\
\hline & $\begin{array}{l}\text { 1. Perusahaan tidak } \\
\text { meningkatkan laba melalui } \\
\text { manajemen laba }\end{array}$ & $\begin{array}{l}\text { 2. Perusahaan } \\
\text { meningkatkan laba } \\
\text { melalui manajemen laba }\end{array}$ \\
\hline $\begin{array}{l}\text { 1. Investor tidak mempercayai bahwa } \\
\text { laba sebelumnya ditingkatkan melalui } \\
\text { manajemen laba }\end{array}$ & $\begin{array}{c}\text { Kolom: } 1.1 \\
(0,0)\end{array}$ & $\begin{array}{c}\text { Kolom: } 1.2 \\
(\mathrm{H},-\mathrm{H})\end{array}$ \\
\hline $\begin{array}{l}\text { 2. Investor mempercayai bahwa laba } \\
\text { sebelumnya ditingkatkan melalui } \\
\text { manajemen laba }\end{array}$ & $\begin{array}{c}\text { Kolom: } 2.1 \\
(-H, H)\end{array}$ & $\begin{array}{l}\text { Kolom: } 2.2 \\
\quad(-C,-C)\end{array}$ \\
\hline
\end{tabular}

Perusahaan yang melakukan penawaran saham dan partisipan pasar sama-sama memiliki dua strategi. Perusahaan dapat meningkatkan laba melalui manajemen laba atau tidak sebelum melakukan penawaran saham. Di sisi lain, investor dapat mempercayai bahwa laba sebelumnya tidak ditingkatkan melalui manajemen laba atau sebaliknya. Jika investor dapat mengetahui tingkat manajemen laba yang dilakukan manajemen, maka hasil yang diperoleh akan ekuilibrium seperti di kolom (1.1). Pada kolom 1.1, hanya laba yang tidak dikelola yang dinilai oleh investor untuk menentukan harga saham. Lebih lanjut, harga saham tidak akan dihargai rendah karena investor mempercayai bahwa laba murni hasil kinerja perusahaan bukan hasil dari manajemen laba. 
Bagaimanapun, dalam kenyataannya, investor tidak dapat mengetahui apakah laba telah dikelola atau tidak. Dengan demikian, perusahaan memiliki insentif untuk menipu investor dengan cara meningkatkan laba dengan melakukan manajemen laba untuk meningkatkan harga saham. Karena terdapat kemungkinan bahwa investor akan ditipu dengan laba artifisial, investor berasumsi bahwa setiap perusahaan akan meningkatkan laba dengan melakukan manajemen laba sebelum melakukan penawaran saham seperti yang ditampilkan pada kolom (2.2). Bahkan perusahan yang tidak melakukan manajemen labapun akan menderita penurunan harga saham pada saat melakukan penawaran saham karena terdapat asumsi ini. Oleh karena itu, perusahaan akan melakukan manajemen laba guna mengantisipasi asumsi dari investor.

\subsection{SEO dan Manajemen Laba}

Penawaran saham tambahan diterbitkan oleh perusahaan karena perusahaan membutuhkan pendanaan. Tinggi atau rendahnya jumlah pendanaan yang diperoleh tergantung pada harga saham pada saat penawaran (Kothari et al., 2016). Oleh sebab itu, manajer memiliki insentif untuk melakukan manajemen laba guna meningkatkan laba sebelum melakukan penawaran saham untuk mendapatkan pendanaan yang lebih.

Hipotesis respon manajerial mengungkapkan bahwa perusahaan akan melakukan manajemen laba sebelum melakukan penawaran saham sebagai respon rasional manajer dalam rangka mengantisipasi partisipan pasar telah berasumsi bahwa perusahaan melakukan manajemen laba dengan meningkatkan akrual diskresioner (Shivakumar 2000). Lebih dari itu, Graham et al. (2005) melakukan survey terhadap 401 eksekutif perusahaan dan melaporkan bahwa eksekutif perusahaan lebih menyukai menggunakan manajemen laba real daripada manajemen laba akrual sehingga penelitian ini tidak hanya menggunakan proksi manajemen laba akrual tetapi juga manajemen laba real.

Penelitian sebelumnya telah menyediakan bukti mengenai manajemen laba sebelum perusahaan melakukan penawaran saham tambahan. Cohen dan Zarowin (2010) dengan menggunakan data di US menemukan bahwa perusahaan melakukan manajemen laba dengan meningkatkan akrual diskresioner dan merendahkan aliran kas operasi sebelum melakukan penawaran saham tambahan. Penelitian baru-baru ini menemukan hasil serupa yang ditemukan oleh Bhuiyan (2015) dengan menggunakan data di Australia. Berdasarkan argumen yang telah dipaparkan sebelumnya, hipotesis yang diajukan dalam penelitian ini yaitu:

$\mathrm{H1}$ : Akrual diskresioner lebih tinggi sebelum penawaran saham tambahan daripada akrual diskresioner setelah penawaran saham tambahan.

H2: Aliran kas operasi abnormal lebih rendah sebelum penawaran saham tambahan daripada aliran kas operasi abnormal setelah penawaran saham tambahan. 


\section{Metodologi Penelitian}

\subsection{Sampel dan Teknik Pengambilan Sampel}

Sampel penelitian ini terdiri atas seluruh perusahaan nonfinansial yang terdaftar di Bursa Efek Indonesia. Teknik pengambilan sampel adalah purposive sampling dengan kriteria pemilihan sampel yakni perusahaan yang melakukan right issue antara tahun 2005-2013, perusahaan tidak melakukan right issue lebih dari satu kali dalam interval enam tahun, dan perusahaan memiliki data keuangan yang lengkap.

\subsection{Pengukuran Variabel}

\subsubsection{Manajemen Laba Akrual}

Penelitian ini menggunakan akrual diskresioner dengan model Jones modifikasian untuk mengestimasi manajemen laba akrual. Alasan yang mendasari pemilihan model Jones modifikasian karena model ini dianggap sebagai model yang paling baik dalam mendeteksi manajemen laba dibandingkan dengan model lain serta memberikan hasil yang paling kuat (Dechow et al., 1995). Penelitian ini mengestimasi akrual diskresioner dengan Jones modifikasian adalah sebagai berikut:

$\mathrm{TAC}_{\text {it }} / \mathrm{TA}_{\mathrm{it}-1}=\beta_{0}\left(1 / \mathrm{TA}_{\mathrm{it}-1}\right)+\beta_{1}\left(\Delta \mathrm{REV}_{\mathrm{it}} / \mathrm{TA}_{\mathrm{it}-1}\right)+\beta_{2}\left(\mathrm{PPE}_{\mathrm{it}} / \mathrm{TA}_{\mathrm{it}-1}\right)+\varepsilon_{\mathrm{it}}$

TAC merupakan total akrual pada tahun $t$ untuk perusahaan i yang diperoleh dari laba sebelum pos luar biasa dan operasi yang dihentikan dikurangi aliran kas operasi. Perhitungan total akrual secara langsung, laba dikurangi aliran kas operasi, dilakukan untuk menghindari estimasi error (Hribar dan Collins 2002). TAit-1 yaitu aset total pada perusahaan i di tahun sebelumnya (t-1) pada perusahaan i. $\triangle$ REVit merupakan pendapatan untuk perusahaan i pada tahun t dikurangi pendapatan pada tahun t-1. PPEit merupakan aset tetap untuk perusahaan $\mathrm{i}$ pada tahun t. $\beta_{0}, \beta_{1}$, dan $\beta_{2}$ merupakan parameter spesifik perusahaan yang diestimasi.

Model persamaan (1) dimaksudkan untuk mendapatkan parameter spesifik perusahaan yang diestimasi dan total akrual yang diestimasi. Lebih lanjut, model persamaan (2) untuk mendapatkan akrual nondiskresioner:

$N D A=\beta_{0}\left(1 / T A_{i t-1}\right)+\beta_{1}\left[\left(\Delta R E V_{i t}-\Delta R E C_{i t} / T A_{i t-1}\right)\right]+\beta 2\left(P P E_{i t} / T A_{i t-1}\right)$

$\triangle \mathrm{REC}_{\text {it }}$ yaitu piutang untuk perusahaan i pada tahun $\mathrm{t}$ dikurangi piutang pada tahun $\mathrm{t}-1$. NDA merupakan akrual diskresioner dan item-item yang lain sama seperti definisi sebelumnya. Akrual diskresioner diperoleh dengan cara mengurangi total akrual dengan akrual nondiskresioner: 


\subsubsection{Manajemen Laba Real}

Manajemen laba real dalam penelitian ini diukur dengan menggunakan aliran kas operasi abnormal. Penelitian ini mengestimasi aliran kas operasi abnormal dengan menggunakan model yang dikembangkan oleh Roychowdhury (2006) yaitu:

CFOit/Ait-1 $=\alpha 0+\beta 1(1 /$ Ait- 1$)+\beta 2($ Sit/Ait-1 $)+\beta 3(\Delta$ Sit/Ait-1) $+\varepsilon i t$

CFO merupakan aliran kas operasi, sedangkan $S$ merupakan total penjualan pada tahun berjalan dan $\Delta S$ merupakan delta atau perubahan antara total penjualan di tahun berjalan dengan total penjualan di tahun sebelumnya. Model (4) diestimasi berdasarkan kode dua digit per industri. Residual dari hasil persamaan (4) merupakan aliran kas operasi abnormal perusahaan i pada tahun t. Aliran kas operasi normal merupakan fungsi linier dari penjualan dan perubahan dalam penjualan (Cohen et al., 2008; Cohen dan Zarowin 2010). Aliran kas operasi abnormal diperoleh dari aliran kas operasi aktual dikurang aliran kas normal (Roychowdhury 2006).

\section{Analisis dan Pembahasan}

\subsection{Deskripsi Objek Penelitian}

Berdasarkan data yang diperoleh dengan menggunakan purposive sampling, terdapat sampel sejumlah 57 untuk aliran kas operasi abnormal dan 47 untuk akrual diskresioner. Gambaran umum mengenai variabel dalam penelitian ini ditampilkan pada tabel 4.2 dalam bentuk statistik deskriptif sebagai berikut:

Tabel 4.1. Kriteria dan Jumlah Sampel

\begin{tabular}{l|cc}
$\begin{array}{l}\text { Keterangan } \\
\text { Right issue antara tahun 2005-2013 }\end{array}$ & $\begin{array}{c}\text { Sampel } \\
\text { AbCFO }\end{array}$ & $\begin{array}{c}\text { Sampel } \\
\text { DA }\end{array}$ \\
$\begin{array}{l}\text { Right issue yang dilakukan oleh perusahaan finansial antara tahun } \\
2005-2013\end{array}$ & 74 & 199 \\
$\begin{array}{l}\text { Right issue yang diterbitkan lebih dari 1 kali oleh perusahaan yang } \\
\text { sama dalam interval } 6 \text { tahun }\end{array}$ & 8 & 8 \\
$\begin{array}{l}\text { Right Issue dengan data yang tidak memiliki 10 observasi untuk } \\
\text { dilakukan regresi per industri. }\end{array}$ & 2 & 2 \\
$\begin{array}{l}\text { Right issue yang tidak didukung oleh data yang lengkap } \\
\text { Sampel yang memenuhi kriteria }\end{array}$ & 58 & 68 \\
\cline { 2 - 3 } & 57 & 47
\end{tabular}


Tabel 4.2. Statistik Deskriptif

\begin{tabular}{lcc} 
Panel A: Distribusi SEO Per Industri & \multicolumn{2}{c}{ Sampel } \\
Industri (Kode Digit Industri) & AbCFO & DA \\
\hline Industri Pertanian (1) & 6 & 6 \\
Industri Pertambangan (2) & 8 & 7 \\
Industri Kimia dan Industri Dasar (3) & 9 & 7 \\
Industri Lain-lain (4) & 7 & 4 \\
Industri Barang-barang Konsumsi (5) & 6 & 10 \\
Industri Properti, Real Estate dan Konstruksi (6) & 15 & 5 \\
Industri Infrastruktur, Utilitas dan Transportasi (7) & 6 & 47
\end{tabular}

\section{Panel B: Distribusi SEO Per Tahun}

\begin{tabular}{|c|c|c|c|c|}
\hline \multirow{2}{*}{ Tahun } & \multicolumn{2}{|c|}{ Sampel AbCFO } & \multicolumn{2}{|c|}{ Sampel DA } \\
\hline & Jumlah SEO & Frekuensi (\%) & Jumlah SEO & Frekuensi (\%) \\
\hline 2005 & 1 & 0.02 & 1 & 0.02 \\
\hline 2006 & 2 & 0.02 & 1 & 0.04 \\
\hline 2007 & 8 & 0.15 & 7 & 0.14 \\
\hline 2008 & 10 & 0.21 & 10 & 0.18 \\
\hline 2009 & 1 & 0.02 & 1 & 0.02 \\
\hline 2010 & 8 & 0.15 & 7 & 0.14 \\
\hline 2011 & 7 & 0.13 & 6 & 0.12 \\
\hline 2012 & 10 & 0.13 & 6 & 0.18 \\
\hline \multirow[t]{2}{*}{2013} & 10 & 0.17 & 8 & 0.18 \\
\hline & 57 & $100 \%$ & 47 & $100 \%$ \\
\hline
\end{tabular}

\section{Panel C: Statistik Deskriptif}

\begin{tabular}{lrrrrrr} 
Variabel & $\mathrm{N}$ & Rerata & Median & \multicolumn{1}{c}{ Std. } & \multicolumn{1}{c}{ Min. } & Maks. \\
\hline $\mathrm{DA}_{\mathrm{t}+3}$ & 47 & $-0,09$ & $-0,07$ & 0,14 & $-0,81$ & 0,20 \\
$\mathrm{DA}_{\mathrm{t}+2}$ & 47 & $-0,05$ & $-0,06$ & 0,14 & $-0,42$ & 0,46 \\
$\mathrm{DA}_{\mathrm{t} 1}$ & 47 & $-0,07$ & $-0,05$ & 0,16 & $-0,53$ & 0,29 \\
$\mathrm{DA}_{\mathrm{t} 0}$ & 47 & 0,06 & $-0,03$ & 0,51 & $-1,09$ & 2,85 \\
$\mathrm{DA}_{\mathrm{t}-1}$ & 47 & $-0,03$ & $-0,08$ & 0,19 & $-0,37$ & 0,60 \\
$\mathrm{DA}_{\mathrm{t}-2}$ & 47 & $-0,01$ & $-0,07$ & 0,34 & $-0,27$ & 2,15 \\
AbCFO $_{\mathrm{t}+3}$ & 57 & 0,04 & 0,03 & 0,10 & $-0,19$ & 0,42 \\
AbCFO $_{\mathrm{t}+2}$ & 57 & 0,05 & 0,03 & 0,10 & $-0,21$ & 0,36 \\
AbCFO $_{\mathrm{t} 1}$ & 57 & 0,00 & 0,01 & 0,13 & $-0,41$ & 0,31 \\
AbCFO $_{\mathrm{t} 0}$ & 57 & $-0,11$ & 0,03 & 0,56 & $-2,89$ & 0,67 \\
AbCFO $_{\mathrm{t}-1}$ & 57 & $-0,03$ & 0,01 & 0,30 & $-1,79$ & 0,35 \\
AbCFO $_{\mathrm{t}-2}$ & 57 & $-0,09$ & 0,03 & 0,85 & $-6,30$ & 0,62 \\
SEO-Akrual & 730 & 0,03 & 0,00 & 0,18 & 0,00 & 1,00 \\
LEV-Akrual & 730 & 0,70 & 0,54 & 2,78 & 0,00 & 72,73 \\
Loss-Akrual & 730 & 0,29 & 0,00 & 0,45 & 0,00 & 1,00 \\
Size-Akrual & 730 & 533063 & 221647 & 783209 & 174 & 5220616 \\
SEO-Real & 771 & 0,07 & 0,00 & 0,258 & 0,00 & 1,00 \\
ROA-Real & 771 & $-0,13$ & 0,02 & 4,11 & $-112,00$ & 15,00 \\
LEV-Real $_{\text {Size-Real }}$ & 771 & 0,89 & 0,53 & 6,43 & 0,00 & 163,00 \\
\hline
\end{tabular}


DA merupakan akrual diskresioner yang diestimasi sebagai residual dari model persamaan (1) dan tanda $t+3$ sampai t-2 merupakan tanda tahun yang masing-masing mengindikasikan tiga tahun setelah dan dua tahun sebelum peristiwa penawaran saham tambahan. AbCFO merupakan aliran kas operasi abnormal yang diestimasi sebagai residual dari model persamaan (4) dan tanda $t+3$ sampai $t-2$ merupakan tanda tahun yang masing-masing mengindikasikan tiga tahun setelah dan dua tahun sebelum peristiwa penawaran saham tambahan. SEO merupakan Seasoned Equity Offerings yang diukur dengan variabel dummy yaitu bernilai 1 untuk perusahaan yang menerbitkan SEO dan 0 jika tidak. LEV yaitu leverage yang diperoleh dari total hutang dibagi total aset. Loss merupakan variabel dummy yaitu nilai 1 untuk perusahaan yang melaporkan kerugian setelah pajak dan 0 jika tidak. ROA yaitu return on asset yang diperoleh dari laba bersih dibagi dengan total aset. Size merupakan ukuran perusahaan yang diukur dengan total aset.

Hasil statistik deskriptif untuk akrual diskresioner, yang ditampilkan di tabel 4.2 pada panel C, menunjukkan bahwa akrual diskresioner (DA) pada tahun peristiwa penawaran tambahan $\left(_{\text {to }}\right.$ ) memiliki nilai rerata sebesar 0,06 , nilai median sebesar $-0,03$, nilai deviasi standar sebesar 0,51, nilai minimum sebesar $-1,09$ dan nilai maksimum sebesar 2.85.

Hasil statistik deskriptif untuk aliran kas operasi abnormal, yang ditampilkan di tabel 4.2 pada panel C, menunjukkan bahwa aliran kas operasi abnormal pada tahun peristiwa penawaran tambahan $\left(_{\text {to }}\right)$ memiliki nilai rerata sebesar $-0,11$, nilai median sebesar 0,03 , nilai deviasi standar sebesar 0,56, nilai minimum sebesar -2,89 dan nilai maksimum sebesar 0.67.

Secara sekilas, akrual diskresioner pada tahun peristiwa penawaran saham tambahan (to) memiliki nilai rerata lebih besar daripada akrual diskresioner pada tahun setelah ataupun tahun sebelum peristiwa penawaran saham tambahan $(\mathrm{t} 3, \mathrm{t} 2, \mathrm{t} 1, \mathrm{t}-1, \mathrm{t}-2)$. Hasil serupa ditemukan pada aliran kas operasi abnormal. Jika dibandingkan dengan aliran kas operasi abnormal pada tahun setelah ataupun tahun sebelum peristiwa penawaran saham tambahan $(\mathrm{t} 3, \mathrm{t} 2, \mathrm{t} 1, \mathrm{t}-1, \mathrm{t}-2)$, aliran kas operasi abnormal pada tahun peristiwa penawaran saham tambahan (to) memiliki nilai rerata yang lebih kecil. Untuk mendapat gambaran jelas mengenai nilai rerata untuk akrual diskresioner dan aliran kas operasi abnormal dari tahun ke tahun untuk ditampilkan pada berikut ini:

Gambar 4.1. Rerata Akrual Diskresioner dan Aliran Kas Operasi Abnormal

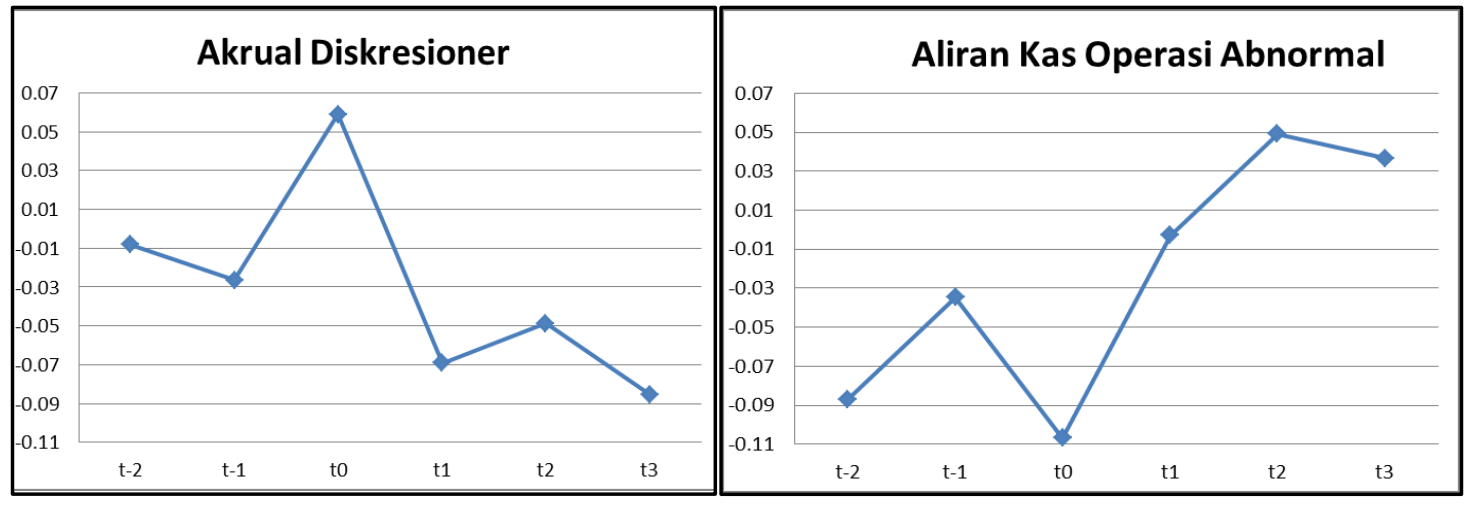

\subsection{Analisis Uji Beda}

Hipotesis dalam penelitian ini berfokus praktik manajemen laba akrual dan real di sekitar peristiwa penawaran saham tambahan. Sebelum melakukan pengujian hipotesis, penelitian ini 
terlebih dahulu melakukan uji normalitas. Asumsi residual data berdistribusi normal tidak terpenuhi, sehingga penelitian ini menggunakan Wilcoxon Signed Rank Test. Ringkasan hasil pengujian hipotesis ditampilkan pada tabel 4,3 sebagai berikut:

Tabel 4.3. Hasil Uji Hipotesis

\begin{tabular}{|c|c|c|c|c|c|c|}
\hline \multicolumn{7}{|c|}{ Panel A: Akrual Diskresioner } \\
\hline Pair & Variabel Sebelum & $>$ & Variabel Setelah & N & Z & Sig. \\
\hline Pair 1 & $\mathrm{DA}_{\mathrm{t} 0}$ & $>$ & $\mathrm{DA}_{\mathrm{t} 1}$ & 47 & -2.307 & $0.021^{\star \star}$ \\
\hline Pair 2 & $\mathrm{DA}_{\mathrm{t} 0}$ & $>$ & $\mathrm{DA}_{\mathrm{t} 2}$ & 47 & -1.556 & 0.120 \\
\hline Pair 3 & $\mathrm{DA}_{\mathrm{t} 0}$ & $>$ & $\mathrm{DA}_{\mathrm{t} 3}$ & 47 & -1.979 & $0.048^{\star \star}$ \\
\hline Pair 4 & $\mathrm{DA}_{\mathrm{t} 0, \mathrm{t}-1}$ & $>$ & $\mathrm{DA}_{\mathrm{t} 1, \mathrm{t} 2}$ & 94 & -1.861 & $0.063^{\star}$ \\
\hline Pair 5 & $\mathrm{DA}_{\mathrm{t} 0, \mathrm{t}-1, \mathrm{t}-2}$ & $>$ & $\mathrm{DA}_{\mathrm{t} 1, \mathrm{t} 2, \mathrm{t} 3}$ & 141 & -1.942 & $0.052^{\star}$ \\
\hline \multicolumn{7}{|c|}{ Panel B: Aliran Kas Operasi Abnormal } \\
\hline Pair & Variabel Sebelum & $>$ & Variabel Setelah & N & Z & Sig. \\
\hline Pair 1 & $\mathrm{AbCFO}_{\mathrm{t} 0}$ & $>$ & $\mathrm{AbCFO}_{\mathrm{t} 1}$ & 57 & -0.306 & 0.760 \\
\hline Pair 2 & $\mathrm{AbCFO}_{\mathrm{t} 0}$ & $>$ & $\mathrm{AbCFO}_{\mathrm{t} 2}$ & 57 & -1.982 & $0.047^{* *}$ \\
\hline Pair 3 & $\mathrm{AbCFO}_{\mathrm{t} 0}$ & $>$ & $\mathrm{AbCFO}_{\mathrm{t} 3}$ & 57 & -1.394 & 0.163 \\
\hline Pair 4 & $\mathrm{AbCFO}_{\mathrm{t} 0, \mathrm{t}-1}$ & $>$ & $\mathrm{AbCFO}_{\mathrm{t} 1, \mathrm{t} 2}$ & 114 & -1.607 & 0.108 \\
\hline Pair 5 & $\mathrm{AbCFO}_{\mathrm{t} 0, \mathrm{t}-1, \mathrm{t}-2}$ & $>$ & $\mathrm{AbCFO}_{\mathrm{t} 1 \mathrm{t} 2, \mathrm{t} 3}$ & 171 & -1.992 & $0.046^{* *}$ \\
\hline
\end{tabular}

Catatan: Tanda ${ }^{*},{ }^{\star *}$, dan ${ }^{* \star *}$ merupakan tanda yang masing-masing mengindikasikan tingkat signifikansi $10 \%, 5 \%$ dan 1\%. DA merupakan akrual diskresioner yang diestimasi sebagai residual dari model persamaan (1) dan tanda $t+3$ sampai ${ }_{\mathrm{t}-2}$ merupakan tanda tahun yang masing-masing mengindikasikan tiga tahun setelah dan dua tahun sebelum peristiwa penawaran saham tambahan. AbCFO merupakan aliran kas operasi abnormal yang diestimasi sebagai residual dari model persamaan (4) dan tanda $t+3$ sampai $t-2$ merupakan tanda tahun yang masing-masing mengindikasikan tiga tahun setelah dan dua tahun sebelum peristiwa penawaran saham tambahan.

Hasil uji beda pada tabel 4.3 di panel A untuk akrual diskresioner, pair 1 menunjukkan bahwa terdapat perbedaan yang signifikan $(0,021)$ antara akrual diskresioner di tahun peristiwa penawaran saham tambahan (to) dengan akrual diskresioner satu tahun setelah peristiwa penawaran saham tambahan $\left.{ }_{(t 1}\right)$. Hasil serupa ditemukan pada pair 3 yang menunjukkan bahwa terdapat perbedaan yang signifikan $(0,048)$ antara akrual diskresioner di tahun peristiwa penawaran saham tambahan (to) dengan akrual diskresioner tiga tahun setelah peristiwa penawaran saham tambahan $\left({ }_{(} 3\right)$. Akan tetapi, hasil uji beda untuk pair 2 menunjukkan bahwa tidak terdapat perbedaan yang signifikan $(0,120)$ antara akrual diskresioner di tahun peristiwa penawaran saham tambahan $\left({ }_{\text {to }}\right)$ dengan akrual diskresioner dua tahun setelah peristiwa penawaran saham tambahan $\left.{ }_{\mathrm{t} 3}\right)$. Penjelasan yang mungkin atas tidak adanya perbedaan yang signifikan di pair 2 karena manajemen laba memiliki sifat berkebalikan (reverse). Dengan kata lain, ketika manajer telah menggunakan akrual diskresioner positif secara agresif pada saat penerbitan SEO, maka di tahun selanjutnya akrual diskresioner akan berarah negatif (Davidson 
et al., 2007). Hal ini terlihat dari Tabel Statistik Deskriptif Panel C dan Gambar 4.1 yang menunjukkan bahwa akrual diskresioner pada tahun ke-2 lebih tinggi daripada akrual diskresioner pada tahun ke-1. Dengan demikian, perbedaan akrual diskresioner antara tahun ke-0 dan tahun ke-2 tidak berbeda signifikan.

Selain itu, penelitian ini membandingkan akrual diskresioner dua tahun sebelum dan dua tahun setelah serta akrual diskresioner tiga tahun sebelum dan tiga tahun setelah penawaran saham tambahan. Hasil uji beda di tabel 4,3 pada pair 4 dan 5 mendukung hasil uji sebelumnya yang menunjukkan bahwa terdapat perbedaan signifikan (masing-masing dengan tingkat signifikan 0,063 dan 0,052) antara akrual diskresioner sebelum penawaran saham tambahan dengan akrual diskresioner setelah penawaran saham tambahan.

Secara keseluruhan, hasil penelitian ini mendukung hipotesis pertama yang menyatakan bahwa akrual diskresioner lebih tinggi sebelum penawaran saham tambahan daripada akrual diskresioner setelah penawaran saham tambahan. Hasil penelitian ini mendukung hasil penelitian Cohen dan Zarowin (2010) dengan menggunakan data di US dan Bhuiyan (2015) dengan menggunakan data di Australia.

Hasil uji beda pada tabel 4.3 di panel B untuk aliran kas operasi abnormal, pair 1 menunjukkan bahwa tidak terdapat perbedaan yang signifikan $(0,760)$ antara aliran kas operasi abnormal di tahun peristiwa penawaran saham tambahan (to) dengan aliran kas operasi abnormal satu tahun setelah peristiwa penawaran saham tambahan $\left({ }_{\mathrm{t} 1}\right)$. Hasil serupa ditemukan pada pair 3 yang menunjukkan bahwa tidak terdapat perbedaan yang signifikan $(0,163)$ antara aliran kas operasi abnormal di tahun peristiwa penawaran saham tambahan (to) dengan aliran kas operasi abnormal tiga tahun setelah peristiwa penawaran saham tambahan $\left({ }_{\mathrm{t} 3}\right)$. Tidak terdapat perbedaan yang signifikan pada pair 1 dan 3 karena manajemen laba memiliki sifat berkebalikan (reverse). Setelah manajemen laba real telah digunakan secara agresif pada saat penerbitan SEO, aliran kas abnormal yang berkebalikan (reverse) yang terjadi di tahun ke-1 tidak pada puncaknya sehingga tidak berbeda signifikan pada tahun ke-0. Pada tahun ke-3, aliran kas abnormal sudah tidak berkebalikan karena telah terjadi pada tahun ke-1 dan ke-2. Hal ini terlihat pada Tabel Statistik Deskriptif Panel C dan Gambar 4.1.

Hasil berbeda ditampilkan pada pair 2 yang menunjukkan bahwa terdapat perbedaan yang signifikan $(0,047)$ antara aliran kas operasi abnormal di tahun peristiwa penawaran saham tambahan (to) dengan aliran kas operasi abnormal dua tahun setelah peristiwa penawaran saham tambahan ${ }_{\mathrm{t} 2}$ ). Lebih lanjut, penelitian ini membandingkan aliran kas operasi abnormal dua dan tiga tahun sebelum dan setelah penawaran saham tambahan. Berdasarkan hasil uji beda di tabel 4.4 , pair 4 menunjukkan bahwa tidak terdapat perbedaan yang signifikan $(0,108)$ antara aliran kas operasi abnormal dua tahun sebelum peristiwa penawaran saham tambahan dengan aliran kas operasi abnormal dua tahun setelah peristiwa penawaran saham tambahan. Hasil berbeda ditemukan pada pair 5 yang menunjukkan bahwa terdapat perbedaan yang 
signifikan $(0,046)$ antara aliran kas operasi abnormal di tahun peristiwa penawaran saham tambahan $\left(_{\text {to }}\right.$ ) dengan aliran kas operasi abnormal tiga tahun setelah peristiwa penawaran saham tambahan.

Dengan demikian, hasil penelitian ini mendukung hipotesis pertama yang menyatakan bahwa akrual diskresioner lebih tinggi sebelum penawaran saham tambahan daripada akrual diskresioner setelah penawaran saham tambahan. Hipotesis kedua terdukung dengan menggunakan data tiga tahun sebelum dan setelah penawaran saham tambahan, dan menggunakan perbandingan tahun pada saat penawaran saham tambahan dengan dua tahun setelah penawaran saham tambahan. Hasil penelitian ini mendukung hasil penelitian Cohen dan Zarowin (2010) dengan menggunakan data di US dan Bhuiyan (2015) dengan menggunakan data di Australia. Lebih lanjut, hasil penelitian ini sesuai dengan teori respon manajerial menjelaskan bahwa perusahaan akan melakukan manajemen laba sebelum melakukan penawaran saham sebagai respon rasional manajer dalam rangka mengantisipasi perilaku partisipan pasar pada saat pengumuman penawaran saham (Shivakumar 2000).

\subsection{Analisis Uji Regresi Berganda}

Tabel 4.4. Hasil Pengujian Regresi

\begin{tabular}{|c|c|c|c|}
\hline $\begin{array}{l}\text { Panel A: } \\
\text { Variabel }\end{array}$ & $\begin{array}{l}11 \text { SEO + } \beta 2 \text { LEV } \\
\text { Expected Sign }\end{array}$ & $\begin{array}{l}\text { Loss }+\beta 4 \\
\text { Koefisien }\end{array}$ & Signifikansi \\
\hline Konstanta & & $-0,065$ & 0,023 \\
\hline SEO & + & 0,189 & $0,000^{\star \star \star}$ \\
\hline LEV & $+/-$ & $-0,004$ & $0,006^{\star \star \star}$ \\
\hline Loss & - & $-0,100$ & $0,000^{\star \star \star}$ \\
\hline Size & $+/-$ & 0,003 & 0,217 \\
\hline F Test (Sig.) & 58,673 & & \\
\hline $\mathrm{N}$ & 730 & & \\
\hline Adj. R Square & 0,240 & & \\
\hline
\end{tabular}

\begin{tabular}{|c|c|c|c|}
\hline $\begin{array}{l}\text { Panel B: } \\
\text { Variabel }\end{array}$ & $\begin{array}{c}0+\beta 1 \text { SEO }+\beta 2 \\
\text { Expected Sign }\end{array}$ & $\begin{array}{l}+\beta 3 \text { LEV + } \\
\text { Koefisien }\end{array}$ & Signifikansi \\
\hline Konstanta & & $-0,072$ & 0,000 \\
\hline SEO & - & $-0,026$ & $0,010^{\star \star *}$ \\
\hline ROA & - & $-0,003$ & $0,000^{\star \star *}$ \\
\hline LEV & $+/-$ & $-0,003$ & $0,000^{* * *}$ \\
\hline Size & $+/-$ & 0,009 & $0,000^{\star \star \star}$ \\
\hline F Test (Sig.) & 27,561 & & \\
\hline $\mathrm{N}$ & 771 & & \\
\hline Adj. R Square & 0,121 & & \\
\hline \multicolumn{4}{|c|}{$\begin{array}{l}\text { Catatan: Tanda }{ }^{*},{ }^{* *} \text {, dan }{ }^{* * *} \text { merupakan tanda yang masing-masing mengindikasikan tingkat signifikansi } 10 \%, 5 \% \\
\text { dan } 1 \% \text {. SEO merupakan peristiwa penawaran saham tambahan yang diukur dengan variabel dummy yaitu nilai } 1 \\
\text { jika perusahaan menerbitkan saham tambahan dan } 0 \text { jika tidak. LEV yaitu leverage yang diperoleh dari total hutang } \\
\text { dibagi total aset. Loss merupakan variabel dummy yaitu nilai } 1 \text { untuk perusahaan yang melaporkan kerugian setelah } \\
\text { pajak dan } 0 \text { jika tidak. Size merupakan ukuran perusahaan yang diproksikan dengan total aset. ROA yaitu return on } \\
\text { asset yang diperoleh dari laba bersih dibagi dengan total aset. }\end{array}$} \\
\hline
\end{tabular}


Penelitian sebelumnya, yang menginvestigasi manajemen laba di sekitar penawaran saham tambahan, hanya menggunakan analisis univariat yang dimungkinkan mendapatkan hasil yang bias karena tidak menyertakan variabel determinan yang lain (Bhuiyan 2015). Selain itu, data yang diobservasi untuk analisis uji beda sangat terbatas. Oleh karena itu, penelitian ini menggunakan analisis regresi berganda untuk mendapatkan hasil yang lebih kokoh. Hasil regresi ditampilkan pada Tabel 4.4 di atas.

Hasil pengujian regresi pada Tabel 4.4 di panel A menunjukkan variabel SEO memiliki koefisien positif $(0,189)$ dengan tingkat signifikansi $1 \%$. Hasil ini memperkuat hasil analisis uji beda yang menunjukkan bahwa perusahaan yang melakukan penawaran saham tambahan berusaha untuk meningkatkan laba dengan menggunakan manajemen laba akrual. Lebih lanjut, hasil pengujian pada panel B menunjukkan bahwa variabel SEO memiliki koefisien negatif ($0,026)$ dengan tingkat signifikansi $1 \%$. Hasil ini memperkuat hasil analisis uji beda yang menunjukkan bahwa perusahaan yang melakukan penawaran saham tambahan berusaha untuk meningkatkan laba dengan menggunakan manajemen laba real. Hasil penelitian ini mendukung hasil penelitian Kim dan Park (2005) serta Cohen dan Zarowin (2010) dengan menggunakan data di US, dan Bhuiyan (2015) dengan menggunakan data di Australia.

\section{Kesimpulan, Keterbatasan, dan Saran}

\subsection{Kesimpulan}

Penelitian ini menguji praktik manajemen laba akrual dan real di sekitar peristiwa penawaran saham tambahan. Penelitian ini berekspektasi bahwa sebelum atau pada saat penawaran saham tambahan dilakukan, laba telah dimanipulasi dengan melakukan manjemen laba akrual dan real.

Penelitian ini menemukan bahwa akrual diskresioner lebih tinggi sebelum atau pada saat penawaran saham tambahan daripada akrual diskresioner setelah penawaran saham tambahan. Selain itu, penelitian ini juga menemukan bahwa aliran kas operasi abnormal lebih rendah sebelum atau pada saat penawaran saham tambahan daripada aliran kas operasi abnormal setelah penawaran saham tambahan.

Implikasi dari penelitian ini adalah perusahaan melakukan manajemen laba sebelum melakukan penawaran saham tambahan dalam rangka untuk meningkatkan harga saham. Hal ini karena tinggi atau rendahnya jumlah pendanaan yang diterima oleh perusahaan tergantung pada harga saham pada saat penawaran (Kothari et al., 2016). 


\subsection{Keterbatasan}

Keterbatasan yang mungkin terjadi dalam penelitian ini adalah jumlah sampel penelitian ini. Sampel dalam penelitian ini terbatas, yakni 47 perusahaan untuk sampel akrual diskresioner dan 57 perusahaan untuk sampel aliran kas operasi abnormal dari 572 perusahaan yang terdaftar di BEI. Penelitian ini tidak menghubungkan manajemen laba pada saat SEO dan harga saham.

\subsection{Saran}

Penelitian selanjutnya dapat menguji apakah manajemen laba pada saat SEO berasosiasi positif terhadap harga saham. Hal ini menarik untuk diteliti lebih lanjut guna mengetahui apakah maksud manajemen dalam memanipulasi laba dapat berhasil untuk meningkatkan harga saham.

\section{Daftar Pustaka}

Ali, A., dan W. Zhang, 2015. CEO Tenure and Earnings Management. Journal of Accounting And Economics 59: 60-79.

Ball R., dan L. Shivakumar. 2008. Earnings Quality At Initial Public Offerings. Journal of Accounting and Economics 45: 324-349.

Bhuiyan, H. U. 2015. Earnings Management around the Seasoned Equity Offerings (SEOs) by Australian Firms: A Multivariate Analysis. Journal of Business Studies 36 (2): 133.

Caton, G. L., C. N. Chiyachantana, C. T. Chua, dan J. Goh. 2011. Earnings Management Surrounding Seasoned Bond Offerings: Do Managers Mislead Ratings Agencies And The Bond Market? Journal of Financial and Quantitative Analysis 46 (3): 687708.

Cheung, Y. L., J. T. Connelly, J. P. Estanislao, P. Limpaphayom, T. Lu, dan S. Utama. 2014. Corporate Governance and Firm Valuation in Asian Emerging Markets. Corporate Governance in Emerging Markets: 27-53.

Cohen, Daniel A., A. Dey, dan T. Z. Lys. 2008. Real and Accrual-Based Earnings Management in the Pre- and Post-Sarbanes-Oxley Periods. The Accounting Review 83 (3): 757-787.

Cohen. D. A., dan P. Zarowin. 2010. Accrual-Based And Real Earnings Management Activities Around Seasoned Equity Offerings. Journal ofAccounting and Economics 50: 2-19.

Davidson, W. N., B. Xie, W. Xu dan Y. Ning. 2007. The Influence Of Executive Age, Career Horizon And Incentives On Pre-Turnover Earnings Management. J Manage Governance 11: 45-60.

Dechow, P. M., R. G. Sloan, dan A. P. Sweeney. 1995. Detecting Earnings Management. The Accounting Review 70 (2): 193-225. 
Alali, F. A., and C. L. Yeh. 2012. Cloud Computing: Overview and Risk Analysis. Journal of Information Systems 26 (2): 13-33.

Graham, John R., Campbell R. Harvey dan Shiva Rajgopal. 2005. The economic implications of corporate financial reporting. Journal of Accounting and Economics 40: 3-73.

Gumanti, T. A. 2001. Earnings Management Pada Penawaran Pasar Perdana Di Bursa Efek Jakarta. Jurnal Riset Akuntansi Indonesia 4 (2): 165-183.

Hribar, P. dan D. W. Collins. 2002. Errors in Estimating Accruals: Implications for Empirical Research. Journal of Accounting Research 40 (1): 105-134.

Jaggi, B., C. L. Chin, H. W. W. Lin, dan P. Lee. 2006. Earnings Forecast Disclosure Regulation And Earnings Management: Evidence From Taiwan IPO Firms. Rev Quant Finan Acc 26: 275-299.

Kim, Yongtae, dan M. S. Park. 2005. Pricing of Seasoned Equity Offers and Earnings Management. Journal of Financial and Quantitative Analysis 40: 435-463.

Kothari, S.P., N. Mizik, dan S. Roychowdhury. 2016. Managing for the Moment: The Role of Earnings Management via Real Activities versus Accruals in SEO Valuation. The Accounting Review 91 (2): 559-586.

Rangan, S. 1998. Earnings Management and The Performance of Seasoned Equity Offerings. Journal of Financial Economics 50: 101-122.

Roychowdhury, Sugata. 2006. Earnings Management Through Real Activities Manipulation. Journal Of Accounting And Economics 42: 335-370.

Shivakumar, L. 2000. Do Firms Mislead Investors by Overstating Earnings Before Seasoned Equity Offerings? Journal of Accounting and Economics 29: 339-371.

Teoh, S. H., T. J. Wong, dan G. R. Rao. 1998a. Are Accruals during Initial Public Offerings Opportunistic? Review of Accounting Studies 3: 175-208.

Teoh, S. H., I. Welch, dan T. J. Wong. 1998b. Earnings Management and The Underperformance of Seasoned Equity Offerings. Journal of Financial Economics 50: 63-99. 